\title{
INFLUENCE OF FARMYARD MANURE ON RETENTION AND AVAILABILITY OF NICKEL, ZINC AND LEAD IN METAL-CONTAMINATED CALCAREOUS LOAM SOILS
}

\author{
Muhammad Abbas AZIZa, Hamaad Raza AHMAD ${ }^{\mathrm{b}}$, Dennis L. CORWINc, Muhammad SABIR ${ }^{\mathrm{b}}$, \\ Khalid Rehman HAKEEM ${ }^{\mathrm{d}}$, Münir ÖZTÜRK ${ }^{\mathrm{e}}$ \\ ${ }^{a}$ Fauji Fertilizer Company, Dera Ghazi Khan, Pakistan \\ ${ }^{b}$ University of Agriculture Faisalabad, 38040 Faisalabad, Pakistan \\ 'USDA Agricultural Research Service, 20250 Washington, United States \\ ${ }^{d}$ Department of Biological Sciences, Faculty of Science, King Abdulaziz University, Jeddah-21589, Saudi Arabia \\ ${ }^{e}$ Botany Department \& Centre for Environmental Studies, Ege University, Izmir, 35100 Bornova, Turkey
}

Submitted 27 Apr. 2016; accepted 26 Oct. 2016

\begin{abstract}
Continuous irrigation of soils with untreated effluents can result in the accumulation and translocation of some metals in the soils and plants. Application of farmyard manure (FYM) to such soils may increase or decrease their availability and retention time. Calcareous soils contaminated with 100,200 , and $400 \mathrm{mg} \mathrm{kg}^{-1} \mathrm{Ni}, \mathrm{Zn}$, and $\mathrm{Pb}$ as chloride salts were used, and farmyard manure added ( $40 \mathrm{~g} \mathrm{~kg}^{-1}$ for 90 days) with moisture contents at field capacity. Soil samples were drawn at 30 day intervals, and metals extracted with (AB-DTPA) $\mathrm{C}_{14} \mathrm{H}_{23} \mathrm{NO}_{3} \mathrm{O}_{10}$. With FYM application of $400 \mathrm{mg} \mathrm{kg}^{-1}$, Ni availability increased from 179 (day 30) to $240 \mathrm{mg} \mathrm{kg}^{-1}$ (day 90); Zn from 163 (day 30) to $230 \mathrm{mg} \mathrm{kg}^{-1}$ (day 90), but, $\mathrm{Pb}$ decreased from 214 to $161 \mathrm{mg} \mathrm{kg}^{-1}$. FYM forms multi-dentate complex which greatly enhances the $\mathrm{Ni}$ and $\mathrm{Zn}$ solubility, and organic matter immobilizes $\mathrm{Pb}$ in the soil.
\end{abstract}

Keywords: availability, nickel, zinc, lead, farmyard manure, contaminated soil.

\section{Introduction}

Irrigation with raw city effluents is becoming a major threat to environment sustainability in many of the developing countries. Raw city effluent is taken as a good source of nutrients, however, depending upon its sources; it can introduce many of the heavy metal elements in soils (Murtaza et al. 2010). From soil, heavy metals can enter into the food chain through the consumption of contaminated food. Prolonged consumption of such contaminated food could pose severe threat to human health. Therefore, management and remediation of metal contaminated soils are very important for producing safe food from such soils. Remediation or cleaning up of contaminated sites with engineering based technologies requires heavy cost and skilled manpower. Moreover, such technologies are disruptive to site and are not considered as environmentally friendly because of the harsh impact of amendments on site properties. Therefore, it is need of time to identify soil amendments for not only improving soil properties but also restraining the mobility and availability of heavy metals to plants and leaching to ground water.

Phytoavailabilty of metals depend upon physical and chemical characteristics of soil such as $\mathrm{pH}$, redox potential, cation exchange capacity, composition and concentration of organic amendments (Pinto et al.2015). Organic amendments like farmyard manure (FYM), press mud, compost etc. not only improve physical, chemical, biological and fertility property of soils, but can also be employed in altering the availability of metal contaminants in soils. Soil-applied animal manures increased the solubility of metals $(\mathrm{Ni}, \mathrm{Zn}$, and $\mathrm{Pb})$ shortly after adding, through the formation of soluble organo-metallic complexes (Almas et al. 1999). There is also the possibility that metals become more tightly bound to organic materials, either through diffusion into or through occlusion in organic molecules (Davis 1984). Metals like $\mathrm{Zn}, \mathrm{Pb}$, and Ni reacted with soil organic matter by ion exchange, complexation, and precipitation reactions, but complexation reactions are thought to dominate (Clemente et al. 2006; Ping et al.

Corresponding author: Khalid Rehman Hakeem

E-mail: kur.hakeem@gmail.com; khakim@kau.edu.sa 
2008). It is well known that the availability of heavy metals decreases with increasing retention of a heavy metal either by silicate clays, calcite, and/or soil organic matter. Such retention of heavy metals is ascribed to reactions between metal ions and soils like adsorption, precipitation, and/or complexation (Alexander 2000; Joner, Leyval 2001; Park et al. 2011). According to Walker et al. (2003) the retention of metals (i.e. $\mathrm{Cu}, \mathrm{Zn}, \mathrm{Mn}, \mathrm{Fe}$, and $\mathrm{Pb}$ ) was greater with manure than with compost. On the other hand, the addition of sewage sludge, increased the mobile fraction of $\mathrm{Zn}, \mathrm{Cd}, \mathrm{Cu}$, and $\mathrm{Ni}$ but decreased that of $\mathrm{Pb}$ compared to the control treatment (Usman et al. 2004). Immobilization of metals by interaction with humic substances could occur through the formation of insoluble complexes or through solid-phase complexation to humates present as coatings on clay surfaces (Stevenson, Cole 1999).

In order to understand the effect of FYM on the availability and retention of heavy metals, detailed information is needed. A large number of studies have been carried out to explore the role of incubation time, type and rate of organic amendments on metal chemical forms and/or fractions in acid and neutral soils (Bataillard et al. 2003; Davies et al. 2003; Lu et al. 2005), however, very little work has been conducted to study the effect of FYM on the availability and retention of heavy metals in calcareous metal contaminated soils. The objective of this study was to understand the effect of FYM on the availability and retention of $\mathrm{Ni}, \mathrm{Pb}$, and $\mathrm{Zn}$ in metal-contaminated calcareous loam soils at different incubation times.

\section{Materials and methods}

\subsection{Soil sampling and analysis}

Soil for the experiment was collected from the plough layer $(0-15 \mathrm{~cm})$ in bulk from a field located in the village 199 RB (Rakh Branch) Gattwala, Faisalabad.Soil belongs to Lyallpur soil series (loamy, mixed, hyperthermic Typic

Table 1. Physical and chemical characteristics of soil used in the study

\begin{tabular}{lcc}
\hline \multicolumn{1}{c}{ Soil characteristics } & Unit & Value \\
\hline $\mathrm{pH}_{\mathrm{s}}$ & - & 7.72 \\
\hline $\mathrm{EC}_{\mathrm{e}}$ & $\mathrm{dS} \mathrm{m}^{-1}$ & 2.4 \\
\hline Organic matter & $\mathrm{g} \mathrm{kg}^{-1}$ & 5.8 \\
\hline $\mathrm{CaCO}_{3}$ & $\mathrm{~g} \mathrm{~kg}^{-1}$ & 54.7 \\
\hline Clay & $\mathrm{g} \mathrm{kg}^{-1}$ & 240.0 \\
\hline Saturation percentage & $\%$ & 34.4 \\
\hline Textural class & - & Loam \\
\hline AB-DTPA extractable metals & 0.33 \\
\hline $\mathrm{Ni}$ & $\mathrm{mg} \mathrm{kg}^{-1}$ & 3.0 \\
\hline $\mathrm{Zn}$ & $\mathrm{mg} \mathrm{kg}^{-1}$ & 2.9 \\
\hline $\mathrm{Pb}$ & $\mathrm{mg} \mathrm{kg}^{-1}$ &
\end{tabular}

Calci-argids) having geographical coordinate viz. longitude $73^{\circ} 11^{\prime} 06^{\prime \prime}$ and latitude $31^{\circ} 27^{\prime} 08^{\prime \prime}$.

Soil was air-dried, thoroughly mixed, and passed through a $2-\mathrm{mm}$ sieve before analysis. These soil samples were analyzed (Table 1) for $\mathrm{pH}_{\mathrm{s}}$ (Jenco $\mathrm{pH}$ meter 6718, Taipei Hsien, Taiwan, R.O.C.), electrical conductivity $\left(\mathrm{EC}_{\mathrm{e}}\right.$ ) by a conductivity meter ( $\mathrm{HI}$ 8033, Hanna Instruments, Woonsocket, USA), particle size distribution by the hydrometer method (Bouyoucos 1962), organic carbon by the Walkley-Black wet combustion method (Nelson, Sommers 1982), and lime $\left(\mathrm{CaCO}_{3}\right)$ by the calcimeter method (Moodie et al. 1959).

Metals were extracted with AB-DTPA. The AB-DTPA extracting solution was prepared by dissolving $79.10 \mathrm{~g}$ $\mathrm{NH}_{4} \mathrm{HCO}_{3}$ and $1.97 \mathrm{~g}$ of DTPA in a liter of solution adjusted to $\mathrm{pH} 7.6$ (Soltanpour 1985). Soil (10 g) was placed in a $250-\mathrm{mL}$ Erlenmeyer flask and $20 \mathrm{~mL}$ of freshly prepared extracting solution was added. The mixture was shaken on a reciprocating shaker at 180 cycles per minute by keeping the flasks uncovered at room temperature. According to Soltanpour (1985) the extractable AB-DTPA solution allows the DTPA to chelate and extract metals efficiently from calcareous soils. The concentration of $\mathrm{Ni}, \mathrm{Zn}$, and $\mathrm{Pb}$ in the filtrate was determined by atomic absorption spectrophotometer (AAS; Thermo S-series, Hitachi, Tokyo, Japan). For artificial spiking of soils, solutions containing 100,200 , and $400 \mathrm{mg} \mathrm{kg}^{-1} \mathrm{Ni}, \mathrm{Zn}$, and $\mathrm{Pb}$ as chloride salts were sprayed onto the soil followed by thorough mixing.

After thoroughly mixing the metal solutions with soil, it was placed in plastic pots (line with polyethylene sheet to check leakage of solution) at $1 \mathrm{~kg}$ soil per pot. Soil was equilibrated in a greenhouse at field capacity (moisture content approximately ( $1 / 3$ bar) equivalent to $50 \%$ of the saturation percentage of soil for 35 days). After the 35-day of equilibration period, the soil was air-dried and passed through a $2-\mathrm{mm}$ sieve again. Air-dried FYM (Table 2) collected from a nearby livestock farm was passed through a $2-\mathrm{mm}$ sieve and mixed uniformly with metal contaminated soil in the amount of $40 \mathrm{~g} \mathrm{~kg}^{-1}$ soil. Plastic pots of 2-L capacity containing experimental soil were arranged in triplicate using a completely randomized design

Table 2. Properties of farmyard manure

\begin{tabular}{lll}
\hline \multicolumn{1}{c}{ Property } & Unit & Value \\
\hline Moisture content & $\mathrm{g} \mathrm{g}^{-1}$ & 0.13 \\
\hline $\mathrm{pH}$ & & 7.75 \\
\hline $\mathrm{EC}(1: 10$ FYM-water slurry) & $\mathrm{dS} \mathrm{m}^{-1}$ & 7.9 \\
\hline Organic carbon & $\mathrm{g} \mathrm{kg}^{-1}$ & 349 \\
\hline Total $\mathrm{N}$ & $\mathrm{g} \mathrm{kg}^{-1}$ & 16.8 \\
\hline Avail. $\mathrm{Ni}$ & $\mathrm{mg} \mathrm{kg}^{-1}$ & 0.10 \\
\hline Avail. $\mathrm{Zn}$ & $\mathrm{mg} \mathrm{kg}^{-1}$ & 0.19 \\
\hline Avail. $\mathrm{Pb}$ & $\mathrm{mg} \mathrm{kg}^{-1}$ & 0.22 \\
\hline
\end{tabular}


and the lids of pots were kept loose to allow gaseous exchange and avoid the build up of $\mathrm{CO}_{2}$ in pots. A similar set of treatments, but without amendments (control), was kept for comparison.

\subsection{Analysis of farmyard manure (FYM)}

The water soluble contents of $\mathrm{Ni}, \mathrm{Pb}$, and $\mathrm{Zn}$ in FYM were determined by preparing slurry with distilled water, i.e., 1:10 (w/v) ratio of FYM to distilled water. The $\mathrm{pH}$ and EC were also measured from the FYM-water slurry. The organic matter of FYM was determined by dry ashing while N was determined by the Kjehldal method (Jackson 1962).

\subsection{Soil incubation and heavy metals determination}

The pots were incubated at room temperature $\left(25 \pm 2{ }^{\circ} \mathrm{C}\right)$ and moisture content $\left(0.13 \mathrm{~g} \mathrm{~g}^{-1}\right)$ was maintained at field capacity throughout the experimentation and adjusted gravimetrically through the addition of distilled water. The soil was incubated for a $90-\mathrm{d}$ period. Soil samples (30 g each) were taken at 30,60 , and 90 days and were extracted with AB-DTPA (Soltanpour 1985). The concentrations of $\mathrm{Ni}, \mathrm{Zn}$, and $\mathrm{Pb}$ were determined using atomic absorption spectrophotometer (AAS; Thermo S-series, Hitachi, Tokyo, Japan).

\subsection{Statistical procedures}

The significant differences between concentrations of $\mathrm{Ni}$, $\mathrm{Zn}$, and $\mathrm{Pb}$ in soils were assessed by ANOVA (Analysis of Variance) and DMR (Duncan's Multiple Range test) using the M STATC version 1.10 packages (MSTAT; East Lansing, MI.) (Russel, Eisensmith 1983) and statistical differences among treatments were defined at $\mathrm{P}<0.05$.

\section{Results and discussion}

\subsection{Soil $\mathbf{p H}$}

The importance of soil $\mathrm{pH}$ on metal availability is well established as it influences the metal adsorption, retention, and transport. Soil $\mathrm{pH}$ was significantly affected by FYM and time during the study (Fig. 1). Soil pH decreased by

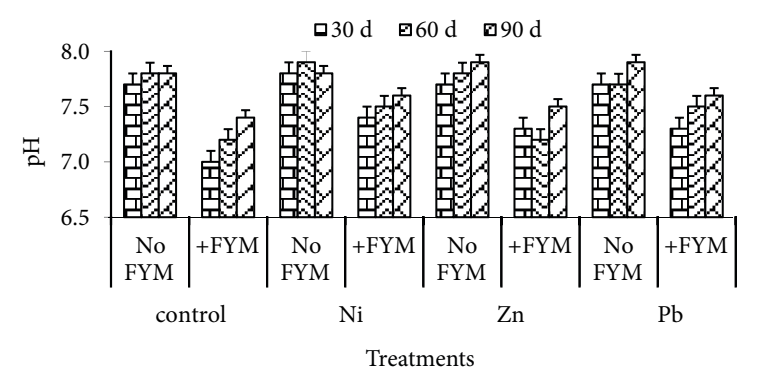

Fig. 1. Effect of FYM addition on soil $\mathrm{pH}$ at different incubation times. [FYM - farmyard manure]

the application of FYM. In the control treatment where no FYM was added it was 7.70 at day 30 , which decreased to 7.00 by the application of FYM. Soil pH decreased from 7.80 to 7.40 by the application of FYM at day 90 in the control. Its values showed a similar trend for $\mathrm{Ni}$, in the absence of FYM it was 7.80 , which decreased to 7.60 with the addition of FYM at day 90 . For $\mathrm{Zn}$ and $\mathrm{Pb}$ the soil $\mathrm{pH}$ decreased from 7.90 to 7.50 and 7.90 to 7.60 , respectively, with the application of FYM at day 90 .

Ostensibly, the decrease in soil pH with FYM application was due to the decomposition of organic matter into humic and fluvic acids, which lower the soil $\mathrm{pH}$ (Stevenson, Cole 1999). As soil pH decreases, metals like $\mathrm{Ni}$ and $\mathrm{Zn}$ must compete with the extra $\mathrm{H}^{+}$and $\mathrm{Al}^{3+}$ for positions on the exchange sites, solubility of these metals increases in the soil solution and a greater proportion is present as highly available free metal ions in the soil solution (McBride 1982; Sauve et al. 1997).

\subsection{Availability of nickel}

Availability of nickel was not significantly affected throughout the study period (Fig. 2). For the control, native Ni was $<1 \mathrm{mg} \mathrm{kg}^{-1}$ and slight mobilization was observed with FYM at a first sampling time, i.e., at day 30 (1.07 mg kg-1), which became $1.65 \mathrm{mg} \mathrm{kg}^{-1}$ at day 90 . At $100 \mathrm{mg} \mathrm{kg}^{-1} \mathrm{Ni}$ application rate, no major change in available Ni was observed without FYM, decreasing from $29.5 \mathrm{mg} \mathrm{kg}^{-1}$ on day 30 to $26.8 \mathrm{mg} \mathrm{kg}^{-1}$ at day 90 . On the other hand, with manure application, the concentration



Fig. 2. Effect of incubation time on availability of Ni. FYM - farmyard manure; $d$ - day. Lower case letters indicate the significance of treatments at $\mathrm{P}<0.05$ 
of $\mathrm{Ni}$ increased and remained higher than that in the unamended soil. With FYM addition, $34.8 \mathrm{mg} \mathrm{kg}^{-1} \mathrm{Ni}$ was in available form at day 30 , which increased to $46.2 \mathrm{mg} \mathrm{kg}^{-1}$ by the end of the experiment. At 200 and $400 \mathrm{mg} \mathrm{kg}^{-1}$ $\mathrm{Ni}$ application rates, $\mathrm{Ni}$ decreased in unamended soil, whereas manure application increased the Ni concentration. Martinez et al. (2003) observed a similar behavior between dissolved organic carbon and soluble Ni concentration in OM-rich soil, i.e., increasing the solubility with incubation time up to 100 days and no further change was observed until the conclusion of the experiment after 600 days. However, the experimental conditions were different as they used natural metal contaminated $\left(\mathrm{Pb} 120 \mathrm{mg} \mathrm{kg}^{-1}\right.$, $\mathrm{Ni}, 800 \mathrm{mg} \mathrm{kg}^{-1}$, and $\mathrm{Zn} 1480 \mathrm{mg} \mathrm{kg}^{-1}$ ) silt loam to sandy clay loam acidic grassland soils.

Ostensibly, the increase in available Ni with FYM was due to the formation of soluble Ni-organic complexes from decomposed organic matter (Fig. 2). The addition of FYM to soil results in the increased dissolved organic matter, which facilitated the mobility of metal in soil by acting as a carrier through formation of soluble metal-organic complexes (McCarthy, Zachara 1989; Mahdavi, Jafari 2010). As organic matter decomposes, more soluble organic compounds are released (Merritt, Erich 2003). Increase or decrease in Ni availability with organic matter depended upon its soluble (fulvic acid) or insoluble constituents like humic acid (McBride 1995). According to Stevenson and Cole (1999), humic and fulvic acids form both soluble and insoluble complexes with Ni. Due to their lower molecular weights and higher contents of acidic functional groups, Ni complexes of fulvic acids are more soluble than those of humic acids. Nickel extracted with DTPA was generally larger with increasing addition of exogenous humic acid solutions than that without humic acid application, which was attributed to the formation of $\mathrm{Ni}$-humic complexes that ensured a temporary bioavailability of $\mathrm{Ni}$ and prevented their rapid transformation into insoluble species (Halim et al. 2003).

The decrease in soil $\mathrm{pH}$ from 7.80 to 7.60 with the addition of FYM at day 90 might be associated with organic matter (OM) decomposition responsible for increased concentration of $\mathrm{Ni}$ in soil as was also found by Heckman et al. (1987), Campbell and Beckett (1988). Similarly, Usman et al. (2004) also attributed the increase in concentration of $\mathrm{Ni}$ in incubated sludge-amended soil to the formation of soluble $\mathrm{Ni}$-organic ligands associations and to a resultant decrease in soil $\mathrm{pH}$ (from 8.14 to 7.54 ) but the soil used was sandy with low organic carbon and not artificially metal incubated. The fast decomposition rate of organic matter could consume oxygen, thus possibly affect the redox conditions of soils, one of the main factors for increasing Ni solubility along with a change in soil $\mathrm{pH}$ and $\mathrm{CO}_{2}$ concentration (Ross 1994).

\subsection{Availability of zinc}

Availability of $\mathrm{Zn}$ showed a similar pattern as was observed in the case of $\mathrm{Ni}$. In the absence of added organic matter, $\mathrm{Zn}$ in the control soil was $3.7 \mathrm{mg} \mathrm{kg}^{-1}$ at day 30 and only $50 \%$ of applied $\mathrm{Zn}\left(1.78 \mathrm{mg} \mathrm{kg}^{-1}\right)$ was recovered at the end of the experiment (Fig. 3). The FYM application decreased extractability of the native $\mathrm{Zn}$ from $3.5 \mathrm{mg}$ $\mathrm{kg}^{-1}$ to $2.4 \mathrm{mg} \mathrm{kg}^{-1}$. In $\mathrm{Zn}$ spiked soil without FYM, Zn decreased at all the sampling times, whereas in manure amended soil, the availability of $\mathrm{Zn}$ gradually increased until the end of the experiment from 163at day 30 to $230 \mathrm{mg} \mathrm{kg}^{-1}$ at day 90 with400 $\mathrm{mg} \mathrm{kg}^{-1}$ of $\mathrm{Zn}$ application, respectively.

The AB-DTPA extractable $\mathrm{Zn}$ in response to FYM added soil increased with time (Fig. 3). Previously Almas et al. (2000) observed the parallel behavior of $\mathrm{Zn}$ but under a different environment as they used acidic clay loam and marine loam soil texture for their experiment; they reported that the addition of organic matter (pig manure) increased the solubility of $\mathrm{Zn}$ through the formation of soluble organo-metallic complexes. Catlett et al. (2002) concluded that binding of $\mathrm{Zn}^{2+}$ with $\mathrm{OM}$ has a significant positive impact on its solubility in fine silty neutral to alkaline calcareous soils. The decomposition of organic matter resulted in the production of low molecular organic acid like acetic, formic, oxalic, lactic, propionic, malic,

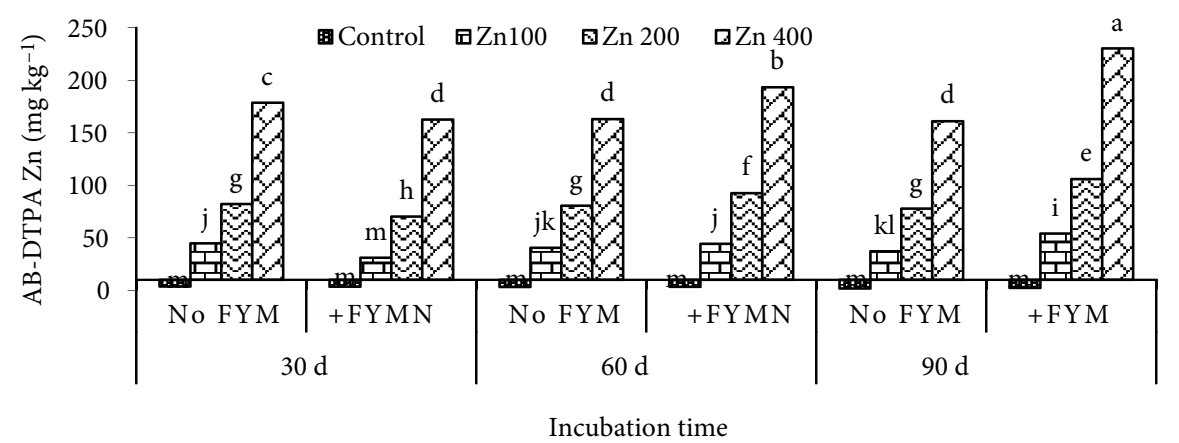

Fig. 3. Effect of incubation time on availability of Zn. FYM - farmyard manure; $d$ - day. Lower case letters indicate the significance of treatments at $\mathrm{P}<0.05$ 
citric, and aconitic acids (Baziramakenga, Simrad 1998) to affect the $\mathrm{pH}$ perturbations as happened in our case the soil $\mathrm{pH}$ decreased 7.90 to 7.50 with the addition of organic matter at day 90 resulting increase in $\mathrm{Zn}$ availability.

At the end of our experiment, soluble organic components might have persisted resulting in higher availability of $\mathrm{Zn}$. In addition, $\mathrm{CaCO}_{3}$ in calcareous soils can lead to $\mathrm{Zn}$ precipitation as $\mathrm{ZnCO}_{3}$ (Usman et al. 2004), but $\mathrm{ZnCO}_{3}$ is soluble, hence more available. According to Lindsay (1979), minerals like $\mathrm{ZnO}$ (zincite) and $\mathrm{ZnCO}_{3}$ (smithsonite) are too soluble to persist in soils. Antoniadis and Alloway (2002) reported increased extractability of $\mathrm{Zn}$ with an increase in dissolved organic carbon in sludge amended soils. In another study, Ashworth and Alloway (2004) found that Zn did not leach from columns filled with sewage sludgeamended sandy loam soil indicating its retention by soil. Pascual et al. (2004) reported lower Ni and Zn concentrations in unamended soil at the end of an incubation period of 64 days than those in the present study.

\subsection{Availability of lead}

Behavior of applied $\mathrm{Pb}$ was different from that exhibited by $\mathrm{Ni}$ and $\mathrm{Zn}$ (Fig. 4). With an incubation of FYM, the Pb availability decreased in metal-contaminated soil. In the unamended control, native $\mathrm{Pb}$ remained unchanged and its concentration was almost the same after 30,60 , and 90 days of incubation. The availability of $\mathrm{Pb}$ from the soil contaminated with 100,200 , and $400 \mathrm{mg} \mathrm{kg}^{-1}$ of $\mathrm{Pb}$ was 52,98 , and $224 \mathrm{mg} \mathrm{kg}^{-1}$, respectively, after 30 days of incubation in the treatments with no FYM, which decreased by 40,86 , and $172 \mathrm{mg} \mathrm{kg}^{-1}$, respectively, after 90 days of incubation. While the availability of $\mathrm{Pb}$ from the soil contaminated with $\mathrm{Pb} \mathrm{100,} 200$ and $400 \mathrm{mg} \mathrm{kg}^{-1}$ on day 30 was 49,104 , and $214 \mathrm{mg} \mathrm{kg}^{-1}$ of the added $\mathrm{Pb}$ in the treatments with FYM, respectively. With FYM amended soil, available $\mathrm{Pb}$ was less than that in unamended soil and was 27,79 , and $161 \mathrm{mg} \mathrm{kg}^{-1}$ of the applied $\mathrm{Pb}$ at the end of the experiment, respectively. At the $100 \mathrm{mg} \mathrm{kg}^{-1}$ application rate, a decrease in availability was more than that at higher levels of $\mathrm{Pb}$ application.
In the present experiment, organic matter has an immobilization effect on $\mathrm{Pb}$ in soil. The AB-DTPA extractable $\mathrm{Pb}$ decreased at all levels of $\mathrm{Pb}$ addition but the decrease was more at the lowest rate of $100 \mathrm{mg} \mathrm{Pb} \mathrm{kg}^{-1}$ of soil (Fig. 3). Similar findings where Clemente et al. (2006) reported EDTA-extractable $\mathrm{Pb}$ decreased from $42.7 \%$ of the total $\mathrm{Pb}$ in control samples to $37.3 \%$ in composttreated samples and to $32.3 \%$ in manure treated samples. However, the experiment was conducted with different environment as they used sandy loam soil and followed McGrath and Cegarra (1992) procedure for metal extraction. Precipitation of $\mathrm{Pb}$ with $\mathrm{CaCO}_{3}$ may also be responsible for the decreased availability of $\mathrm{Pb}$ (McBride 1994; Kumpiene et al. 2008). Over a 90 -day incubation period, mobile $\mathrm{Pb}$ decreased to $0.62 \%$ of the total $\mathrm{Pb}$ contents in soil treated with compost (Usman et al. 2004). Precipitation of $\mathrm{Pb}, \mathrm{Zn}, \mathrm{Cd}$, and $\mathrm{Cu}$ as insoluble compounds appeared to become important at approximately $\mathrm{pH}$ 6-7. At $\mathrm{pH}$ values of around 6 or 7 , very little $\mathrm{Pb}$ is likely to be found in solution (Ram, Verloo 1985). This was attributed to the products like humic and fulvic acids resulting from decomposition of organic matter with which $\mathrm{Pb}$ formed stable organo-metallic complexes alone and in association with soil clays. As pointed out by Stevenson and Cole (1999), both fulvic and humic acids form soluble as well as insoluble complexes depending upon the degree of saturation. The importance of organic matter in limiting $\mathrm{Pb}$ availability has also been demonstrated by Strawn and Sparks (2000) and Saini and Gupta (2001).

\section{Conclusions}

From a soil and groundwater contamination point of view the retention of heavy metal in soil and their availability to plants is important. A calcareous loam soil was tested to investigate the effect of FYM on the availability of applied $\mathrm{Ni}, \mathrm{Zn}$, and $\mathrm{Pb}$ over a period of time. The availability of $\mathrm{Ni}$ and $\mathrm{Zn}$ increased with incubation time, but $\mathrm{Pb}$ availability decreased over time. Ostensibly, added FYM formed soluble organo-metallic complexes with $\mathrm{Ni}$, and $\mathrm{Zn}$ increasing their availability with time. Whereas a decrease

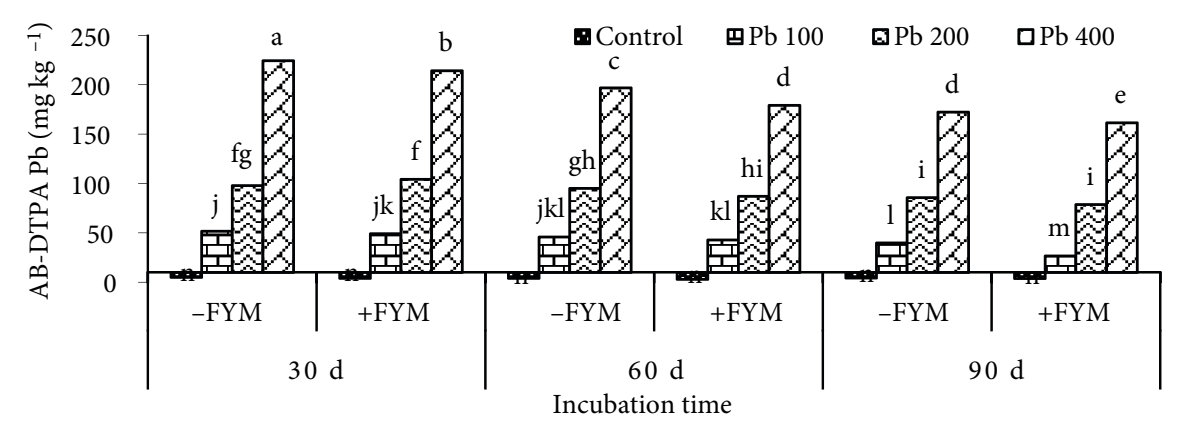

Fig. 4. Effect of incubation time on availability of $\mathrm{Pb}$. FYM - farmyard manure; $\mathrm{d}$ - day. Lower case letters indicate the significance of treatments at $\mathrm{P}<0.05$ 
in $\mathrm{Pb}$ availability might be due to the presence of $\mathrm{CaCO}_{3}$ resulting in its precipitation. The general order of affinity of heavy metal retention is as follows $\mathrm{Cu}>\mathrm{Zn}>\mathrm{Pb}$.

Increased availability of $\mathrm{Ni}$, and $\mathrm{Zn}$ with the application of farmyard manure could result in an increased risk to soil and groundwater resources. Continuous application of FYM with the passage of time not only significantly reduced metal sorption, but also increased their mobility through the formation of soluble metal complexes in alkaline soils and contaminates the groundwater through leaching of metals from these soils. During the application of FYM the nature, composition, physico-chemical properties of soil and microbial activities should be considered. More studies are needed to understand the phenomena of the increased availability of heavy metal by the addition of FYM and to prevent plants from their phytotoxic effect. However, the increased bioavailability of heavy metals by the application of farmyard manure can be used while phytoremediating the contaminated sites.

\section{Disclosure statement}

Authors declare no conflict of interest among them.

\section{References}

Alexander, M. 2000. Aging, bioavailability, and overestimation of risk from environmental pollutants, Environmental Science \& Technology 34: 4259-4264. https://doi.org/10.1021/es001069+

Almas, A. R.; McBride, M. B.; Singh, B. R. 2000. Solubility and liability of cadmium and zinc in two soils treated with organic matter, Soil Science 165: 250-259.

https://doi.org/10.1097/00010694-200003000-00007

Almas, A. R.; Singh, B. R.; Salbu, B. 1999. Mobility of cadmium and zinc in soil influenced by equilibration, time, temperature and organic matter, Journal of Environmental Quality 28: 1742-1750.

https://doi.org/10.2134/jeq1999.00472425002800060008x

Antoniadis, V.; Alloway, B. J. 2002. The role of dissolved organic carbon in the mobility of $\mathrm{Cd}, \mathrm{Ni}$ and $\mathrm{Zn}$ in sewage sludgeamended soils, Environmental Pollution 117: 515-521. https://doi.org/10.1016/S0269-7491(01)00172-5

Ashworth, D. J.; Alloway, B. J. 2004. Soil mobility of sewage sludge-derived organic matter, copper, nickel and zinc, Environmental Pollution 127: 137-144. https://doi.org/10.1016/S0269-7491(03)00237-9

Bataillard, P.; Cambier, P.; Picot, C. 2003. Short-term transformation of lead and cadmium compounds in soil after contamination, European Journal of Soil Science 54: 365-376. https://doi.org/10.1046/j.1365-2389.2003.00527.x

Baziramakenga, R.; Simrad, R. R. 1998. Low molecular weight aliphatic acid contents of composted manure, Journal of Environmental Quality 27: 557-561. https://doi.org/10.2134/jeq1998.00472425002700030012x

Bouyoucos, G. J. 1962. Hydrometer method improved for making particle-size analyses of soils, Agronomy Journal 54: 464465.

https://doi.org/10.2134/agronj1962.00021962005400050028x
Campbell, D. J.; Beckett, P. H. T. 1988. The soil solution in a soil treated with digested sewage sludge, European Journal of Soil Science 39: 283-298. https://doi.org/10.1111/j.1365-2389.1988.tb01215.x

Catlett, K. M.; Heil, D. M.; Lindsay, W. L. 2002. Ebinger MH. Soil chemical properties controlling zinc ${ }^{2+}$ activity in 18 Colorado soils, Soil Science Society of America Journal 66: 1182-1189. https://doi.org/10.2136/sssaj2002.1182

Clemente, R.; Escolar, A.; Bernal, M. P. 2006. Heavy metals fractionation and organic matter mineralization in contaminated calcareous soil amended with organic materials, Bioresource Technology 97: 1894-1901. https://doi.org/10.1016/j.biortech.2005.08.018

Davies, N. A.; Hodson, M. E.; Black, S. 2003. The influence of time on lead toxicity and bioaccumulation determined by OECD earthworm toxicity test, Environmental Pollution 121 : 55-61. https://doi.org/10.1016/S0269-7491(02)00207-5

Davis, J. A. 1984. Complexation of trace metals by adsorbed natural organic matter, Geochimica et Cosmochimica Acta 48: 679-691. https://doi.org/10.1016/0016-7037(84)90095-4

Halim, M.; Conte, P.; Piccolo, A. 2003. Potential availability of heavy metals to phytoextraction from contaminated soils induced by exogenous humic substances, Chemosphere 52: 265-275. https://doi.org/10.1016/S0045-6535(03)00185-1

Heckman, J. R.; Angle, J. S.; Chaney, R. L. 1987. Residual effects of sewage sludge on soybean: I. accumulation of heavy metals, Journal of Environmental Quality16: 113-117. https://doi.org/10.2134/jeq1987.00472425001600020004x

Jackson, M. L. 1962. Chemical composition of soil, in F. E. Bean (Ed.). Chemistry of soil. New York: Van Nostrand Rchinheld Co., 71-144.

Joner, E. J.; Leyval, L. C. 2001. Time-course of heavy metal uptake in maize and clover as affected by root density and different mychorrhizal inoculation regimes, Biology and Fertility of Soils 33: 351-357. https://doi.org/10.1007/s003740000331

Kumpiene, J.; Lagerkvist, A.; Maurice, C. 2008. Stabilization of $\mathrm{As}, \mathrm{Cr}, \mathrm{Cu}, \mathrm{Pb}$ and $\mathrm{Zn}$ in soil using amendments - a review, Waste Manage 28: 215-225. https://doi.org/10.1016/j.wasman.2006.12.012

Lindsay, W. 1979. Chemical equilibrium in soils. New York, NY, USA: John Wiley and Sons.

Lu, A.; Zhang, S.; Shan, X. 2005. Time effect on the fraction of heavy metals in soils, Geoderma 125: 225-234. https://doi.org/10.1016/j.geoderma.2004.08.002

Mahdavi, M.; Jafari, J. 2010. Environmental risks due to application of sewage sludge in farmlands, Ozean Journal of Applied Sciences 3: 303-311.

Martinez, C. E.; Jacobson, A. R.; McBride, M. B. 2003. Ageing and temperature effect on DOC and elemental release from a metal contaminated soil, Environmental Pollution 122: 135143. https://doi.org/10.1016/S0269-7491(02)00276-2

McBride, M. B. 1982. Electron spins resonance investigation of $\mathrm{Mn}^{2+}$ complexation in natural and synthetic organics, Soil Science Society of America Journal 46: 1137-1143. https://doi.org/10.2136/sssaj1982.03615995004600060004x

McBride, M. B. 1994. Environmental chemistry of soils. New York, NY, USA: Oxford Univ. Press.

McBride, M. B. 1995. Toxic metal accumulation from the use of sludge: are USEPA regulations protective?, Journal of Environmental Quality 24: 5-18. https://doi.org/10.2134/jeq1995.00472425002400010002x 
McCarthy, J. F.; Zachara, J. M. 1989. Subsurface transport of contaminants, Environmental Science \& Technology 23: 496-502. https://doi.org/10.1021/es00063a001

McGrath, S. P.; Cegarra, J. 1992. Chemical extractability of heavy metals during and after long-term application of sewage sludge to soil, European Journal of Soil Science 43(2): 313321. https://doi.org/10.1111/j.1365-2389.1992.tb00139.x

Merritt, K. A.; Erich, M. S. 2003. Influence of organic matter decomposition on soluble carbon and its copper-binding capacity, Journal of Environmental Quality 32(6): 2122-2131. https://doi.org/10.2134/jeq2003.2122

Moodie, C. D.; Smith, H. W.; McCreery, R. A. 1959. Laboratory manual for soil fertility. Washington State College, Mimeograph, USA, 31-39.

Murtaza, G.; Ghafoor, A.; Qadir, M.; Owens, G.; Aziz, M. A.; Zia, M. H.; SAIFULLAH. 2010. Disposal and use of sewage on agricultural lands in Pakistan: a review, Pedosphere 20: 23-34. https://doi.org/10.1016/S1002-0160(09)60279-4

Nelson, D. W.; Sommers, L. E. 1982. Total carbon, organic carbon, and organic matter, in A. L. Page, et al. (Eds.). Methods of soil analysis. Part 2. Chemical and microbiological properties. 2nd ed. Agronomy Monograph No. 9. American Society of Agronomy, Soil Science Society of America, 539-577.

Park, J. H.; Lamb, D.; Paneerselvam, P.; Choppala, G.; Bolan, N.; Chung, J. W. 2011. Role of organic amendments on enhanced bioremediation of heavy metal (load) contaminated soils, Journal of Hazardous Materials 185(2-3): 549-574. https://doi.org/10.1016/j.jhazmat.2010.09.082

Pascual, I.; Antolin, M. C.; Garcia, C.; Polo, A.; Sanchez-Diaz, M. 2004. Plant availability of heavy metals in a soil amended with a high dose of sewage sludge under drought conditions, Biology and Fertility of Soils 40(5): 291-299. https://doi.org/10.1007/s00374-004-0763-1

Ping, Li.; Xingxiang, W.; Taolin, Z.; Dongmei, Z.; Yuanqiu, H. E. 2008. Effects of several amendments on rice growth and uptake of copper and cadmium from a contaminated soil, Journal of Environmental Sciences 20(4): 449-455. https://doi.org/10.1016/S1001-0742(08)62078-1

Pinto, E.; Almeida, A. A.; Ferreira, I. M. P. L. V. O. 2015. Assessment of metal(loid)s phytoavailability in intensive agricultural soils by the application of single extractions to rhizosphere soil, Ecotoxicology and Environmental Safety 113: 418-424. https://doi.org/10.1016/j.ecoenv.2014.12.026

Ram, N.; Verloo, M. 1985. Effect of various organic materials on the mobility of heavy metals in soil, Environmental Pollution Series B, Chemical and Physical 10(4): 241-248. https://doi.org/10.1016/0143-148X(85)90017-5

Ross, S. M. 1994. Retention, transformation and mobility of toxic metals in soils, in S. M. Ross (Ed.). Toxic metals in soil-plant system. Chi Chester, UK: Jhon Wiley and Sons. Ltd., 63-152.

Russel, D. F.; Eisensmith, S. P. 1983. MSTAT-C. Crop Soil Science Department, Michigan State University, East Lansing, Mich. USA.

Saini, S. P.; Gupta, V. K. 2001. Lead and FYM influence on yield and $\mathrm{Pb}$ concentration of wheat sown on sandy and clay loam soils, Journal of the Indian Society of Soil Science 49: 508-510.

Sauve, S.; McBride, M. B.; Norvell, W. A.; Hendershot, W. H. 1997. Copper solubility and speciation of in situ contaminated soils: effects of copper level, $\mathrm{pH}$ and organic matter, Water, Air, and Soil Pollution100: 133-149. https://doi.org/10.1023/A:1018312109677

Soltanpour, P. N. 1985. Use of AB-DTPA to evaluate elements availability and toxicity, Communications in Soil Science and Plant Analysis 16: 323-338.

Stevenson, F. J.; Cole, M. A. 1999.Cycles of soils: carbon, nitrogen, phosphorus, sulfur, micronutrients. $2^{\text {nd }}$ ed. New York, NY, USA: John Wiley and Sons.

Strawn, D, G.; Sparks, D. L. 2000. Effects of soil organic matter on the kinetics and mechanisms of $\mathrm{Pb}$ (II) sorption and desorption in soil, Soil Science Society of America Journal 64: 144-156. https://doi.org/10.2136/sssaj2000.641144x

Usman, A. R. A; Kuzyakov, Y.; Stahr, K. 2004. Dynamics of organic $\mathrm{C}$ mineralization and the mobile fraction of heavy metals in calcareous soils incubated with organic wastes, Water, Air, and Soil Pollution 158(1): 401-418. https://doi.org/10.1023/B:WATE.0000044864.07418.8f

Walker, D. J.; Clemente, R.; Rig, A; Bernal, M. P. 2003. The effects of soil amendments on heavy metal bioavailability in two contaminated Mediterranean soils, Environmental Pollution 122(2): 303-312. https://doi.org/10.1016/S0269-7491(02)00287-7

Muhammad Abbas AZIZ. Dr, PhD. Presently working for Fauji fertilizers, Pakistan. He has published ten papers in wellreputed refereed national and international journals. He also got William Roberts scholarship and HEC indigenous merit scholarship for PhD sponsored by Pakistan Government.

Hamaad Raza AHMAD. Dr, PhD. Working as Assistant professor at Institute of Soil and Environmental Sciences, University of Agriculture, Faisalabad, Pakistan. He has published more than fifty research articles in well-reputed refereed national and international journals. He has guided $21 \mathrm{MSc}$ (Hons.) thesis and acted as committee member of 16 students. He also got Postdoc fellowship from HEC, Pakistan.

Dennis CORWIN. PhD. Working as Research Soil and Environmental Scientist at USDA-ARS United States Salinity Laboratory, Riverside.CA., YSA. He has more than 150 publications in well-reputed international journals. He got seven awards including American Society of Agronomy Fellow (2014) and Soil Science Society of America Fellow (2014). He is the Editor of many world reputed journals.

Muhammad SABIR. Dr, PhD. Working as Assistant professor at Institute of Soil and Environmental Sciences, University of Agriculture, Faisalabad, Pakistan. He has won Postdoc fellowships from HEC, Pakistan and Malaysian Governments. He has published more than fifty research articles in well-reputed refereed national and international journals. He has guided $23 \mathrm{MSc}$ (Hons.) thesis and acted as committee member of 14 students. 
Khalid Rehman HAKEEM. PhD. Currently, working as Associate Professor at King Abdulaziz University, Jeddah, Saudi Arabia, has worked at Universiti Putra Malaysia from (2012-2016) as Post Doc fellow and Fellow Researcher (Ass. Prof.) subsequently. He has more than nine (09) years of teaching/research experience in Biological sciences. He has a proven track record of over 60 research publications in highly reputed professional journals, in the fields of Plant stress physiology, soil science, ecology and environmental sciences, in addition to 50 chapters in international books and guest editorship of "The Malaysian Forester-Malaysia" and "Sains Malaysiana". Dr. Hakeem has published 21 books with International publishers and is a recipient of more than 5 honours and awards. Presently, Dr. Hakeem in studying the plant processes at Eco-physiological, as well as Proteomic levels.

Münir ÖZTÜRK. Dr, PhD. He is retired Professor of Ecology and Environmental Sciences. He has a proven track record of over 125 research publications in highly reputed professional journals, in the fields of ecology, environmental sciences and ethnobotany, in addition to 50 chapters in international books and guest editorship of "The Malaysian ForesterMalaysia", "Environmental Geology-Springer", "Journal of Environmental Biology-India" "Social and Behavioral Sciences Procedia-Elsevier". Has published more than 30 books (Daya Publishers, Cambridge Scholars, Birkhauser Verlag, Springer and Elsevier), and is a recipient of more than 15 honours and awards. 